\title{
Pinocchio shows how to end the tobacco epidemic
}

\author{
Stanton A Glantz
}

Department of Medicine and Center for Tobacco Control Research and Education University of California, San Francisco, California

\section{Correspondence to}

Stanton A Glantz, Professor of Medicine, Center for Tobacco Control Research and Education, University of California, Box 1390, Room 366 University Library, San Francisco, CA 94143-1390, USA; glantz@medicine.ucsf.edu

Received 20 April 2011 Accepted 30 July 2011
When Tobacco Control published its first issue in 1992, the idea of ending the tobacco epidemic was not even on the horizon. Indeed, the goal was merely to get control of the problem.

Now, 20 years later, serious people are discussing ending tobacco as a public health problem. Finland and New Zealand have officially established the goal of doing so by 2040 and 2025, respectively. While specific efforts are just beginning to take shape, even establishing such a goal would have seemed silly even a few years ago.

One important reason that it now makes sense is that we have proven technologies to cut tobacco use that have been successfully enacted and implemented by policy makers. ${ }^{1}$ Smoke-free environments, strong anti-tobacco media (especially when it confronts the tobacco industry directly) and substantial tax increases all undermine the social acceptability of tobacco use and reinforce the tobacco-free norm in rich countries and in countries with emerging economies. ${ }^{2}$

There is a new broad appreciation that smoking in the movies is a major key media channel promoting tobacco use worldwide for both youth ${ }^{34}$ and young adults. $^{5-9}$ (The tobacco companies have known this since the 1920s and spent decades quietly using film to promote smoking. ${ }^{10}$ ) In the USA, smoking in movies accounts for $44 \%$ of youth initiation. ${ }^{12}$ The relative importance of onscreen smoking is likely to be more important in countries with greater restrictions on conventional tobacco marketing. ${ }^{13} 14$ There is a dose-response for the effect of smoking in movies on smoking behaviour. ${ }^{34}$ This consensus has led to a broad effort ${ }^{4}$ to reduce onscreen smoking by integrating tobacco into film rating systems to give an adult content rating for tobacco use in films. Because producers are unlikely to accept a less profitable adult rating just to keep smoking in a film they hope to market to youth, there will be an economic incentive to leave tobacco out of films designed to be marketed to youth, substantially reducing the level of exposure and consequent effects on youth initiation. There has already been substantial progress in reducing the amount of smoking onscreen. ${ }^{15}$

In addition to direct regulation, policies could create market incentives that would lead the tobacco companies themselves to change their marketing techniques. For example, governments could impose fees on the companies based on the amount of their products consumed by children each year. ${ }^{16}$ The companies, of course, loudly claim that they do not want kids to smoke (or chew or snus) while profiting for decades by creating new addicts. Setting this fee at the discounted present value of all future consumption of their products by these new young consumers would remove the economic benefit to the companies of addicting children. Setting the fee at an increasing multiplier over time would create an active economic disincentive for recruiting new young smokers and other tobacco users. In order to maximise profits, the companies would then have to implement increasingly aggressive steps to avoid attracting youth to their products.

Policy makers can be shown that, contrary to conventional wisdom, aggressive general market tobacco control programmes (not ones focused on youth) have rapid positive impacts on healthcare costs because of rapid reductions in heart disease and, a bit later, cancer. The California tobacco control programme started impacting health costs after just one year, an effect that grew to $7 \%$ of health costs after 15 years. ${ }^{17}$ Similar, albeit smaller, results were observed in Arizona, which has a less aggressive programme. ${ }^{18}$ As non-communicable diseases and healthcare cost containment move to centre stage globally, eliminating tobacco use becomes the obvious first and biggest step to make progress. ${ }^{19} 20$

Another important development has been the broad acceptance of the tobacco industry as a vector that spreads disease and corrupts the policymaking process. ${ }^{21}$ The understanding that it is important to insulate the policymaking process from the tobacco industry led directly to WHO Framework Convention on Tobacco Control Article 5.3 that seeks to insulate policy making from industry influence. ${ }^{22}$ It has also led public health advocates around the world to urge other organisations and politicians to refuse the industry's money and 'partnerships. ${ }^{23-28}$

All these steps have reduced the industry's legitimacy, which both undermines their political power and creates an environment in which consumers do not want to affiliate with the tobacco companies by buying their products. ${ }^{25} 2930$

Of course, none of this will be easy. The companies are always on the lookout to buy or seduce friends and political protection or to promote new 'reduced harm' products ${ }^{31}$ and 'responsible regulation. ${ }^{32}$ We need to avoid such seductions and keep in mind the fact that the tobacco companies always follow the strategies that they think will maximise profits in the long run.

But, the end is in sight.

In early 2011, a friend showed her 21/2-year-old granddaughter Walt Disney's 1940 Pinocchio, a cartoon filled with smoking.

The little girl did not know what the characters were doing. She had to have it explained.

That would not have happened in 1992.

Funding This work was funded in part by National Cancer Institute grant CA-61021. The funding agency played no role in the preparation of the manuscript. National Cancer Institute Other Funders: NIH.

Competing interests None.

Provenance and peer review Commissioned; externally peer reviewed. 


\section{REFERENCES}

1. Centers for Disease Control and Prevention. Best Practices for Comprehensive Tobacco Control Programs. Atlanta, GA: U.S. Department of Health and Human Services, Centers for Disease Control and Prevention, National Center for Chronic Disease Prevention and Health Promotion, Office on Smoking and Health, 2007. http://www.cdc.gov/tobacco/tobacco_control_programs/stateandcommunity/ best_practices/.

2. Crosbie E, Sebrie EM, Glantz SA. Strong advocacy led to successful implementation of smokefree Mexico City. Tob Control 2011;20:64-72.

3. National Cancer Institute. Tobacco Control Monograph 19: The Role of the Media in Promoting and Reducing Tobacco Use. Bethesda, MD: National Cancer Institute, 2008. http://cancercontrol.cancer.gov/tcrb/monographs/19/index.html laccessed 30 Sep 2008).

4. World Health Organization. Geneva Smoke-Free Movies: From Evidence to Action: World Health Organization, 2009. http://www.who.int/tobacco/smoke_free_movies/ en/ (accessed 16 Aug 2011).

5. Song AV, Ling PM, Neilands TB, et al. Smoking in movies and increased smoking among young adults. Am J Prev Med 2007;33:396-403.

6. Shmueli D, Prochaska J, Glantz SA. The effect of exposure to smoking scenes in films on immediate smoking: a controlled laboratory study. Am J Prev Med 2010;38:351-8

7. Wagner DD, Dal Cin S, Sargent JD, et al. Spontaneous action representation in smokers when watching movie characters smoke. J Neurosci 2011;31:894-8.

8. Sargent JD, Morgenstern M, Isensee $B$, et al. Movie smoking and urge to smoke among adult smokers. Nicotine Tob Res 2009;11:1042-6.

9. Lochbuehler $\mathbf{K}$, Voogd $\mathrm{H}$, Scholte $\mathrm{RH}$, et al. Attentional bias in smokers: exposure to dynamic smoking cues in contemporary movies. J Psychopharmacol 2011:25:514-19.

10. Lum K, Polansky J, Jackler RK. Signed, sealed and delivered: "big tobacco" in Hollywood, 1927-1951. Tob Control 2008;17:313-23.

11. Mekemson C, Glantz SA. How the tobacco industry built its relationship with Hollywood. Tob Control 2002;11(Suppl 1):181-91.

12. Millett C, Glantz SA. Assigning an '18' rating to movies with tobacco imagery is essential to reduce youth smoking. Thorax 2010;65:377-8.

13. Anderson SJ, Millett C, Polansky JR, et al. Exposure to smoking in movies among British adolescents 2001-2006. Tob Control 2010;19:197-200.

14. Millett C, Polansky JR, Glantz S. Government inaction on ratings and government subsidies to the US film industry help promote youth smoking. PLoS Medicine 8: e1001077. doi:10.1371/journal.pmed.1001077.

15. Centers for Disease Control and Prevention. Smoking in top-grossing movies United States, 2010. MMWR Morb Mortal Wkly Rep 2011;60:909-13.
16. Glantz SA. Removing the incentive to sell kids tobacco. A proposal. JAMA 1993;269:793-4

17. Lightwood JM, Dinno A, Glantz SA. Effect of the California tobacco control program on personal health care expenditures. PLoS Med 2008:5:e178.

18. Lightwood J, Glantz SA. Effect of the Arizona tobacco control program on cigarette consumption and healthcare expenditures. Soc Sci Med 2011;72:166-72.

19. Beaglehole R, Bonita R, Horton R, et al. Priority actions for the non-communicable disease crisis. Lancet 2011;377:1438-47

20. Glantz S, Gonzalez M. Effective tobacco control is the key to rapid progress in reducing noncommunicable diseases. Lancet Published online first 29 Sept 2011 doi:10.1016/S0140-6736(11)60615-6

21. World Health Organization. Tobacco Company Strategies to Undermine Tobacco Control Activities at the World Health Organization 2000, 2000. http://www.who.int/ tobacco/en/who inquiry.pdf.

22. World Health Organization. WHO Framework Convention on Tobacco Control (2008) Guidelines for Implementation of Article 5.3: Guidelines on the Protection of Public Health Policies with Respect to Tobacco Control from Commercial and Other Vested Interests 2008, 2008. http://www.who.int/fctc/guidelines/article 5 3/en/.

23. Cohen JE. Universities and tobacco money. BMJ 2001;323:1-2.

24. Sebrie EM, Glantz SA. Attempts to undermine tobacco control: tobacco industry "youth smoking prevention" programs to undermine meaningful tobacco control in Latin America. Am J Public Health 2007;97:1357-67.

25. McDaniel PA, Smith EA, Malone RE. Philip Morris's project sunrise: weakening tobacco control by working with it. Tob Control 2006;15:215-23.

26. Tesler LE, Malone RE. Corporate philanthropy, lobbying, and public health policy. Am J Public Health 2008;98:2123-33.

27. Yang JS, Malone RE. "Working to shape what society's expectations of us should be": Philip Morris' societal alignment strategy. Tob Control 2008;17:391-8.

28. Yerger VB, Malone RE. African American leadership groups: smoking with the enemy. Tob Control 2002;11:336-45.

29. Ling PM, Neilands TB, Glantz SA. The effect of support for action against the tobacco industry on smoking among young adults. Am J Public Health 2007:97:1449-56.

30. Ling PM, Neilands TB, Glantz SA. Young adult smoking behavior: a national survey. Am J Prev Med 2009;36:389-94.

31. Mejia AB, Ling PM, Glantz SA. Quantifying the effects of promoting smokeless tobacco as a harm reduction strategy in the USA. Tob Control 2010; 19:297-305.

32. McDaniel PA, Malone RE. Understanding Philip Morris's pursuit of US government regulation of tobacco. Tob Control 2005;14:193-200.

\section{Invited commentary}

Stanton A Glantz, in 'Pinocchio shows how to end the tobacco epidemic', ${ }^{1}$ wishes for better insulation of the policy-making process from interference by tobacco companies. Poland provides a vivid example of how important this is. The parliamentary debate (2008-2010) about the revision of Poland's Tobacco Act revealed how strong the influence of the tobacco industry on public health policy remains in Poland. Although great strides were made in increasing smoke-free areas, particularly in hospitality venues, this progress was undermined by a weakening of the enforcement provisions. Requirements for enforcement and fines for violations were actually stronger in the original Act. During the course of 2011, the tobacco industry has also orchestrated a campaign in Poland against the revision of the European Union Tobacco Products Directive and pictorial warnings' regulation ${ }^{2}$ and also organised mass media campaigns on the growing problem of smuggling in Poland with the cooperation of Customs Service and Ministry of Justice, Ministry of Economy and Ministry of Interior and Administration. ${ }^{3}$ They are making the argument that effective tobacco control measures encourage illicit tobacco trade along with devastating Polish tobacco farmers' incomes. These arguments have clearly been persuasive to key government departments and journalists alike. Although Poland is a party to the WHO
Framework Convention on Tobacco Control and is thus bound by Article 5.3, awareness of tobacco industry tactics and history of dishonesty is low among decision makers, opinion leaders and the general population. The tobacco industry is still regarded by decision makers as a credible and reliable partner for discussions about public health and tobacco control regulations-definitely not as a vector that spreads disease and corrupts the policymaking process.

The Ministry of Health announced ${ }^{4}$ that it is now in the process of drafting further revisions to the Tobacco Act to try to address some of the weaknesses introduced by the tobacco industry and its supporters. Unless the issue of tobacco industry interference in health policy is confronted, this effort will be seriously undermined. Because of the country's leading position in the region, this is of critical importance not only to Poland but to its neighbours as well.

\section{Łukasz Balwicki}

Correspondence to Dr Łukasz Balwicki, Department of Public Health and Social Medicine, Medical University of Gdansk, Poland; balwicki@gumed.edu.pl

Competing interests None.

Provenance and peer review Commissioned; internally peer reviewed.

Tobacco Control 2012;21:297-298. doi:10.1136/tobaccocontrol-2011-050410 